\title{
Planning of Number and Location of New Base Transceiver Station (BTS) Tower in Mobile Telecommunication System in Jombang Using Analytical Hierarchy Process Method and Geographic Information System Approach
}

\author{
Achmad Mauludiyanto \\ Department of Electrical Engineering \\ Institut Teknologi Sepuluh Nopember \\ Surabaya, Indonesia \\ maulud@ee.its.ac.id, achmadmauludiyanto@gmail.com
}

\author{
Yoga Dwi Pranata \\ Department of Electrical Engineering \\ Institut Teknologi Sepuluh Nopember \\ Surabaya, Indonesia \\ yogapranata.elits@g.ncu.edu.tw
}

\begin{abstract}
Technology and telecommunication industry has been growing rapidly. Operators continue to race to be able to improve its services. One of them is the development of BTS to be able to serve mobile users in the area to be reached. But development without proper planning can have a bad impact in the future. This research discussed about the location arrangement and number of BTS in Jombang regency up to 5 years according to Analytical Hierarchy Process method with population density criteria, Spatial Plans (SP) and distance and will be displayed in digital map based on geographic information system. For 2014 there are 204 towers in Jombang while for 2019 it takes 231 towers to cover the needs of the people of Jombang Regency.
\end{abstract}

Keywords- BTS, Coverage, Traffic Capacity, Geographic Information System, Analytical Hierarchy Process

\section{INTRODUCTION}

Service availability is pursued by a number of operators offering various systems and services that vary with the development of cellular radio network infrastructure, including in addition to the number and location of BTS Tower which is a compulsory requirement.

If viewed from the opposite viewpoint, the density of the tower location is too high to bring some problems that affect the community. On the one hand, the increasing number of tower sites will indeed support the fulfillment of the community's need for telecommunication services. On the other hand, if development is done without coordination it will disturb the beauty of a region.

To be able to solve the problem of location and number of BTS tower in Jombang need a complete and detailed Master Plan about location planning and number of BTS tower in Jombang regency. The Master Plan must continue to comply with applicable regulations.
In this research will be discussed about the location planning and the number of new BTS towers in Jombang. The result of this final project will be displayed in digital map using Map Info and the determination of new BTS location based on Analytical Hierarchy Process method.

This study aims to find out the location of existing towers and traffic capacity in Jombang regency that will be useful to determine the number of base stations needed for the next 5 years. And can know the location and number of new BTS towers in Jombang.

This research is focused on Jombang Regency which will be displayed in Map Info and BTS location determination based on Analytical Hierarchy Process method with population density criteria, Spatial Plans and Distance.

\section{RESEARCH METHODOLOGY}

A. Literature Study

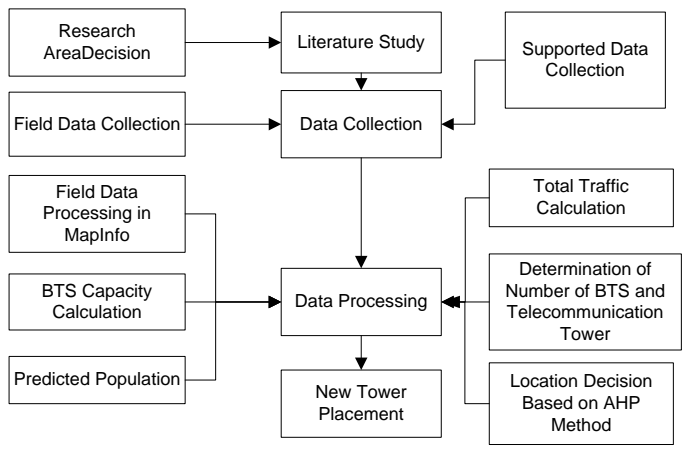

FIGURE 1 RESEARCH FLOWCHART

The area used for research is Jombang District. Jombang Regency is located at 5020 '01 "to 50 30' 01" East Longitude and 07024 '01 "and 070 45' 01" South Latitude, with an area of $1,159.50 \mathrm{Km} 2$. Jombang Regency is divided into 21 districts 
consisting of 302 villages and 4 sub-districts and includes 1,258 hamlets

\section{B. Data Collection}

The data required in this study is divided into two:

a. Field data, ie data obtained by conducting direct surveys to the field such as the tower coordinate point capture, tower height, determination of the number of base stations, and mobile operators operating in the tower.

b. Supporting data, ie data obtained from other sources such as legal basis, digital map usage, population data, Spatial Plan, existing tower zone, new tower zone, and tower free zone in Jombang regency.

\section{Data Calculation}

The parameters used to calculate the needs of the BTS number of Jombang Regency are:

a. The average mobile user call for the suburban area is 60 minutes and for the rural area is 45 minutes. So Offered Traffic per customer can be calculated:

Rural : $\mathrm{A}=45 /(24$ X 60) $=31,25$ mErlang

Suburban : $A=60 /(24$ X 60) $=41,67$ mErlang

b. Grade of Service (GOS) is assumed $2 \%$

c. BTS capacity used has configuration

a) Menggunakan Using 3 sectoral antennas with $3 / 3 / 3$ configuration

1 sector consists of $3 \mathrm{TRx}$

1 TRx consists of 8 timeslots

$3 \mathrm{TRx}=8 \times 3=24$ timeslots

1 sector of 3 TRx can serve 24-2 = 22 Channels.

b) Each BTS consists of 3 sectoral antennas with each sector consisting of $3 \mathrm{TRx} /$ sectoral antennas so the number of channels per BTS is $22 \times 3=66$ channels.

c) Capacity 1 BTS consisting of 3 sectoral antennas and each sectoral antenna consisting of $3 \mathrm{TRx}$ and GOS assumption of $2 \%=55.33$ Erlang (Referring to Table Erlang B). [5]

\section{Determination of Criteria and sub criteria in Determining} Location of BTS with AHP Method

In the BTS location planning can be assumed criteria and sub criteria as follows

a. Population Density

The assessment criteria of population density are as follows:

a. Good

The definition of good judgment is through the amount of population in the kecamatan including high population.

b. Enough

The definition of sufficient appraisal is that the population of the subdistrict population is not densely populated but does not include low population.

c. Less

Definition of less assessment is through the population of the population in the kecamatan include low population.

b. Spatial Plans

The assessment criteria of Spatial Plans are as follows: a. Good

The definition of good judgment is through regional funding that is included in the main program Spatial Plans Jombang District.

b. Enough

The definition of sufficient assessment is through the regional funding included in the Jombang Spatial Plans program but not included in the main program.

c. Less

Definition of less assessment is through regional funding that is not included in the program Spatial Plans (SP) Jombang District.

c. Distance

The assessment criteria of distance are as follows:

a. Good

The definition of good judgment is through the spacing of new tower zones with areas belonging to suburban and industrial areas as the most densely populated areas in Jombang Regency fall into the suburban category.

b. Enough

The definition of appraisal is sufficient through the spacing of new tower zones with areas that are included in the residential area as it supports the activities of the people of Jombang Regency.

c. Less

The definition of scant assessment is through the spacing of new tower zones with areas with fewer residential areas and many forests or open areas.

\section{E. Calculation of criteria with AHP Method}

Criteria to be calculated with the assessment are:
a. Density: good, enough, less
b. SP: good, enough, less
c. Distance: well, enough, less

The steps that must be taken to assess the location of BTS with AHP method is:

a. Matrix of pairing criteria

This step is to compare one criterion with another. The results can be seen in table 1 .

TABLE 1 MATCHED COMPARISON MATRICES

\begin{tabular}{|l|c|c|c|}
\hline Criteria & Density & SP & Distance \\
\hline Density & 1 & 2 & 3 \\
\hline SP & 0.5 & 1 & 1.5 \\
\hline Distance & 0.33 & 0.67 & 1 \\
\hline Total & 1.83 & 3.67 & 5.5 \\
\hline
\end{tabular}

From Table 1, the AHP method is written to determine the value of pairwise comparison matrices, namely population density is more important 2 times than SP. Population density is more important 3 times than distance. While SP 0.5 times more important than population density. SP 1.5 times more important than distance

Then from the specified matrix values are added vertically (the same column) to produce the total value of each population density criteria, SP, and distance. 


\section{b. Criteria Value Matrix}

The value of this matrix is obtained by dividing the row value of Table 1 by the number of each column Table 1 . While the value in the priority column is obtained from dividing the value in the sum column by the number of criteria. Example: in the density column a value of 0.55 (Table 2) is obtained from the value of 1 column density (in Table 1) divided by total density (Table 1). In Table 2 the Priority column value of 0.55 is obtained from the total value of 1.65 divided by the number of criteria i.e. 3. And so on for all available columns. The results of the calculation can be seen in table 2 .

TABLE 2 CRITERIA VALUE MATRIX

\begin{tabular}{|l|c|c|c|c|c|}
\hline Criteria & Density & SP & Distance & Total & Priority \\
\hline Density & 0.55 & 0.54 & 0.54 & 1.65 & 0.55 \\
\hline SP & 0.27 & 0.27 & 0.27 & 0.82 & 0.27 \\
\hline Distance & 0.18 & 0.18 & 0.18 & 0.54 & 0.18 \\
\hline
\end{tabular}

\section{c. Sum of each line matrix}

The value of this matrix is obtained by multiplying the priority value in table 2 with the value of each row of columns in table 1. Example: In Table 3, the column density value 0.55 is obtained by multiplying the density priority row 0.55 (Table 2) with the column density value 1 (Table 1 ). A column value of 0.28 is obtained by multiplying 0.55 by a density value of 0.5 (Table 1). The column value of 0.18 is obtained by multiplying 0.55 by the density value of 0.33 (Table 1 ). And so on for all available columns. While the sum of the columns in table 3 is derived from summing the values in each row in table 3 . The calculation results can be seen in Table 3 .

TABLE 3 SUM OF EACH LINE MATRIX

\begin{tabular}{|l|c|c|c|c|}
\hline Criteria & Density & SP & Distance & Total \\
\hline Density & 0.55 & 0.54 & 0.54 & 1.63 \\
\hline SP & 0.28 & 0.27 & 0.27 & 0.83 \\
\hline Distance & 0.18 & 0.18 & 0.18 & 0.54 \\
\hline
\end{tabular}

\section{d. Consistency Ratio}

Consistency ratio is calculated to prove whether $\mathrm{CR}<=0.1$. If the Consistency Ratio has reached $<=0.1$ then the matrix can be used. To be able to calculate the consistency ratio can be calculated using table 4 .

TABLE 4 CONSISTENCY RATIO

\begin{tabular}{|l|l|l|l|}
\hline Criteria & $\begin{array}{l}\text { Total } \\
\text { each line }\end{array}$ & Priority & Result \\
\hline Density & 1.63 & 0.55 & 2.18 \\
\hline SP & 0.83 & 0.27 & 1.10 \\
\hline Distance & 0.54 & 0.18 & 0.27 \\
\hline \multicolumn{3}{|c|}{ Total } & 4.00 \\
\hline
\end{tabular}

The number of columns per row is obtained from the number field in Table 3. While the priority columns are obtained from the priority columns in Table 2. From Table 4 we can obtain the values:

a. The number of criteria is 3

b. $\lambda \max$ is $4 / 3=1.33$

$\lambda \max$ is obtained by dividing the total in Table 4 by the number of criteria (i.e. 3$)$

c. $\mathrm{CI}$ is $((1.33-3) / 3)=-0.55$

$\mathrm{CI}$ (Consistency Index) is the difference $\lambda$ max with the number of criteria divided by the number of criteria

d. $\mathrm{CR}$ is $(-0.55 / 0.58)=-0.94$

CR (Consistency Ratio) is the value of CI divided by RI (Random Index)

\section{F. Calculation of subcriteria with AHP Method}

Subcriteria calculations are performed for all sub-sub of all existing criteria. Subcriteria calculation is the same way with criteria calculation. Steps are as follows.

a. Comparison matrix in pairs

This step is the same as the step in table 1. The calculation results are shown in table 5.

TABLE 5 MATCHED COMPARISON MATRICES DENSITY CRITERIA

\begin{tabular}{|l|l|l|l|}
\hline & Good & Enough & Less \\
\hline Good & 1 & 3 & 5 \\
\hline Enough & 0.33 & 1 & 3 \\
\hline Less & 0.20 & 0.33 & 1 \\
\hline Total & 1.53 & 4.33 & 9 \\
\hline
\end{tabular}

\section{b. Criteria Value Matrix}

This step is the same as the step in table 2 but there is addition of priority sub criteria and sub criteria. The value in the priority sub criteria column is derived from the priority value in that row divided by the highest value in the priority column. While the value of sub-criteria obtained from multiplication between the priority sub criteria with the priority criteria. The results can be seen in table 6 .

TABLE 6 MATRIX OF DENSITY CRITERIA VALUES

\begin{tabular}{|l|l|l|l|l|l|l|l|}
\hline & $\begin{array}{l}\text { Goo } \\
\mathrm{d}\end{array}$ & $\begin{array}{l}\text { Enoug } \\
\mathrm{h}\end{array}$ & $\begin{array}{l}\text { Les } \\
\mathrm{s}\end{array}$ & $\begin{array}{l}\text { Tota } \\
\mathrm{l}\end{array}$ & $\begin{array}{l}\text { Priorit } \\
\mathrm{y}\end{array}$ & $\begin{array}{l}\text { Priorit } \\
\text { y sub } \\
\text { criteria }\end{array}$ & $\begin{array}{l}\text { Value } \\
\text { sub } \\
\text { criteri } \\
\mathrm{a}\end{array}$ \\
\hline Good & 0.65 & 0.69 & $\begin{array}{l}0.5 \\
6\end{array}$ & 1.90 & 0.63 & 1.00 & 0.55 \\
\hline $\begin{array}{l}\text { Enoug } \\
\mathrm{h}\end{array}$ & 0.22 & 0.23 & $\begin{array}{l}0.3 \\
3\end{array}$ & 0.78 & 0.26 & 0.41 & 0.23 \\
\hline Less & 0.13 & 0.08 & $\begin{array}{l}0.1 \\
1\end{array}$ & 0.32 & 0.11 & 0.17 & 0.09 \\
\hline
\end{tabular}

While the other steps are the same as the steps on the priority criteria calculation before. While the differences in paired matrix comparison for subcriteria of Spatial Plans and Distance criteria can be seen in Table 7 and Table 8 . 
TABLE 7 MATRIX CRITERIA PAIR CRITERIA SPATIAL PLAN

\begin{tabular}{|l|l|l|l|}
\hline & Good & Enough & Less \\
\hline Good & 1 & 2 & 6 \\
\hline Enough & 0.5 & 1 & 2 \\
\hline Less & 0.17 & 0.5 & 1 \\
\hline
\end{tabular}

TABLE 8 MATRIX CRITERIA PAIRE CRITERIA DISTANCE

\begin{tabular}{|l|l|l|l|}
\hline & Good & Enough & Less \\
\hline Good & 1 & 3 & 4 \\
\hline Enough & 0.33 & 1 & 3 \\
\hline Less & 0.25 & 0.33 & 1 \\
\hline
\end{tabular}

\section{DISCUSSION}

\section{A. Mobile User Data}

Teledensity of mobile users is the ratio between the number of mobile users and the population in the area in this case is Jombang. Teledensity of cellular users in Jombang can be assumed by teledensity of cellular users in East Java which is $56.5 \%$. Teledensity of mobile users by region can be seen in figure 2. Teledensity serves as seeing the number of mobile users in a region.wilayah.

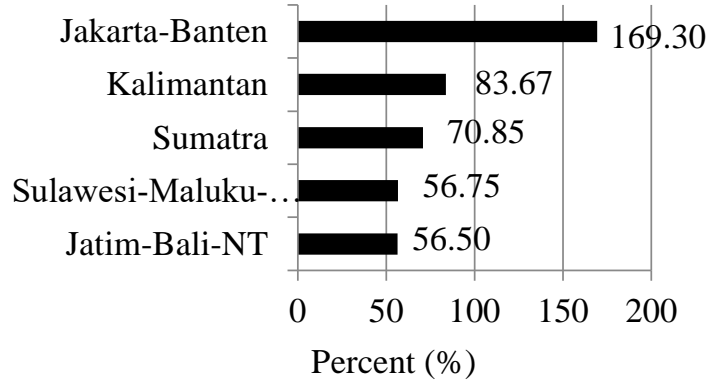

FIGURE 2 CELLULAR PHONE USER BY REGION OF 2010

According to the population data in Jombang Dalam Figures 2013, information can be obtained about the population of each sub-district and population growth data of each sub-district in Jombang Regency in 2012. Using geometric formula about population growth, it can be calculated the prediction of population for next 5 years and shown in table 9 .

$$
\mathrm{P}_{2019}=\mathrm{P}_{2014}(1+\mathrm{X})^{\mathrm{t}}
$$

TABLE 9 POPULATION PREDICTION

\begin{tabular}{|l|l|l|l|}
\hline District & $\begin{array}{l}\text { Growth } \\
\text { Rate }\end{array}$ & $\begin{array}{l}\text { Population } \\
\text { in 2014 }\end{array}$ & $\begin{array}{l}\text { Population } \\
\text { Prediction } \\
\text { in 2019 }\end{array}$ \\
\hline $\begin{array}{l}\text { Bandar Kedung } \\
\text { Mulyo }\end{array}$ & $0,63 \%$ & 44.300 & 45.714 \\
\hline Perak & $0,59 \%$ & 52.089 & 53.644 \\
\hline Gudo & $0,65 \%$ & 51.805 & 53.511 \\
\hline Diwek & $0,58 \%$ & 103.335 & 106.367 \\
\hline Ngoro & $0,59 \%$ & 70.508 & 72.613 \\
\hline Mojowarno & $0,56 \%$ & 87.560 & 90.040 \\
\hline Bareng & $0,59 \%$ & 50.651 & 52.163 \\
\hline Wonosalam & $0,56 \%$ & 31.305 & 32.192 \\
\hline Mojoagung & $0,58 \%$ & 74.718 & 76.911 \\
\hline Sumobito & $0,59 \%$ & 78.887 & 81.242 \\
\hline
\end{tabular}

\begin{tabular}{|l|l|l|l|}
\hline District & $\begin{array}{l}\text { Growth } \\
\text { Rate }\end{array}$ & $\begin{array}{l}\text { Population } \\
\text { in 2014 }\end{array}$ & $\begin{array}{l}\text { Population } \\
\text { Prediction } \\
\text { in 2019 }\end{array}$ \\
\hline Jogoroto & $0,50 \%$ & 64.222 & 65.844 \\
\hline Peterongan & $0,59 \%$ & 65.306 & 67.256 \\
\hline Jombang & $0,64 \%$ & 140.791 & 145.355 \\
\hline Megaluh & $0,71 \%$ & 37.556 & 38.909 \\
\hline Tembelang & $0,69 \%$ & 50.479 & 52.245 \\
\hline Kesamben & $0,67 \%$ & 61.626 & 63.719 \\
\hline Kudu & $0,74 \%$ & 29.087 & 30.180 \\
\hline Ngusikan & $0,71 \%$ & 21.532 & 22.308 \\
\hline Ploso & $0,67 \%$ & 39.849 & 41.202 \\
\hline Kabuh & $0,81 \%$ & 40.382 & 42.045 \\
\hline Plandaan & $0,79 \%$ & 36.456 & 37.919 \\
\hline Total & $0,64 \%$ & 1.232 .444 & 1.271 .379 \\
\hline
\end{tabular}

\section{B. Total Costumer Traffic}

The per-user traffic assumption in the suburban area is 41.67 mErlang while the rural area is 31.25 mErlang. Then the traffic per user is calculated by multiplying the number of users with the intensity of the region's traffic. While the number of users is obtained from the multiplication of population with teledensity of mobile users in East Java that is equal to $56.5 \%$. If you can know the traffic in a region then it can be known also the optimal number of base stations in the region. Then the total result of customer traffic can be seen in table 10 .

TABLE 10 TOTAL USER TRAFFIC IN JOMBANG DISTRICT IN 2019

\begin{tabular}{|l|l|l|l|}
\hline District & $\begin{array}{l}\text { Total } \\
\text { User } \\
\mathbf{2 0 1 9}\end{array}$ & $\begin{array}{l}\text { Morphology } \\
\text { Area }\end{array}$ & $\begin{array}{l}\text { Total Traffic } \\
\mathbf{2 0 1 9} \\
\text { (Erlang) }\end{array}$ \\
\hline $\begin{array}{l}\text { Bandar Kedung } \\
\text { Mulyo }\end{array}$ & 25.829 & Rural & 808 \\
\hline Perak & 30.309 & Rural & 948 \\
\hline Gudo & 30.234 & Rural & 945 \\
\hline Diwek & 60.098 & Rural & 1.879 \\
\hline Ngoro & 41.027 & Rural & 1.283 \\
\hline Mojowarno & 50.873 & Rural & 1.590 \\
\hline Bareng & 29.473 & Rural & 922 \\
\hline Wonosalam & 18.189 & Rural & 569 \\
\hline Mojoagung & 43.455 & Rural & 1.358 \\
\hline Sumobito & 45.902 & Rural & 1.435 \\
\hline Jogoroto & 37.202 & Rural & 1.163 \\
\hline Peterongan & 38.000 & Rural & 1.188 \\
\hline Jombang & 82.126 & Sub-Urban & 1970 \\
\hline Megaluh & 21.984 & Rural & 687 \\
\hline Tembelang & 29.519 & Rural & 923 \\
\hline Kesamben & 36.002 & Rural & 1126 \\
\hline Kudu & 17.052 & Rural & 533 \\
\hline Ngusikan & 12.605 & Rural & 394 \\
\hline Ploso & 23.280 & Rural & 728 \\
\hline Kabuh & 23.756 & Rural & 743 \\
\hline Plandaan & 21.425 & Rural & 670 \\
\hline Total & 718.340 & & 22.459 \\
\hline
\end{tabular}

\section{Determination of Number of BTS and Telecommunication Tower}

The calculation of the number of base stations needed in Jombang District for 2019 was obtained by dividing the total traffic generated by mobile users (Erlang) with the capacity of 1 BTS in Jombang District. Capacity 1 BTS (E) consisting of 3 sectoral antennas with each sectoral antenna consisting of 3 
TRx assuming 2\% GOS is 55.33 Erlang (Referred to Erlang B Table). While the number of towers is calculated by:

$\mathrm{M}_{\mathrm{t}}=(($ Total BTS in2019 - Total BTSin 2014)/4) $)+$ Total Tower in 2014

The calculation result of BTS and Telecommunication Tower for the year 2019 is shown in table 11.

TABLE 11 TOTAL NEEDS OF BTS AND CELLULAR

TELECOMMUNICATION TOWER TOGETHER IN 2019

\begin{tabular}{|l|l|l|l|l|}
\hline Pistrict & Total & Total & Total Tower & $\begin{array}{l}\text { Total Tower } \\
\text { BTS 2014 }\end{array}$ \\
\hline $\begin{array}{l}\text { BTS 2019 } \\
\text { Kandar } \\
\text { Medung }\end{array}$ & 12 & 15 & 7 & 8 \\
\hline Perak & 19 & 18 & 11 & 11 \\
\hline Gudo & 15 & 18 & 9 & 10 \\
\hline Diwek & 26 & 34 & 15 & 17 \\
\hline Ngoro & 19 & 24 & 15 & 17 \\
\hline Mojowarno & 19 & 29 & 10 & 13 \\
\hline Bareng & 9 & 17 & 5 & 7 \\
\hline Wonosalam & 13 & 11 & 10 & 10 \\
\hline Mojoagung & 28 & 25 & 10 & 10 \\
\hline Sumobito & 16 & 26 & 10 & 13 \\
\hline Jogoroto & 13 & 22 & 7 & 10 \\
\hline Peterongan & 19 & 22 & 8 & 9 \\
\hline Jombang & 50 & 47 & 34 & 37 \\
\hline Megaluh & 9 & 13 & 6 & 7 \\
\hline Tembelang & 17 & 17 & 9 & 9 \\
\hline Kesamben & 10 & 21 & 9 & 12 \\
\hline Kudu & 9 & 10 & 8 & 9 \\
\hline Ngusikan & 2 & 8 & 2 & 4 \\
\hline Ploso & 16 & 14 & 8 & 8 \\
\hline Kabuh & 12 & 14 & 7 & 51 \\
\hline Plandaan & 10 & 13 & 4 & 204 \\
\hline Total & 343 & 418 & & 8 \\
\hline
\end{tabular}

\section{Determination of the Number and Location of the New} Tower Zone

Determination of the number of new tower zones can be calculated using the formula:

Zone Total $=($ Total BTS in $2014-$ Total BTS in 2019) $/ 4$

Zone Total $=((433-343) / 4)=23$ Zone

The new tower zone in this final project uses a finger of 0.5 $\mathrm{km}$ and the area of each new tower zone can be calculated by the formula:

The area of the new tower zone $=3.14 \mathrm{X} 0.5 \mathrm{X} 0.5=0.785 \mathrm{Km}^{2}$ The total area of 23 new tower zones is calculated formula: Area total zone $=23 \times 0,785=18,055 \mathrm{Km}^{2}$

The location of the new tower zone can be seen in Table 12 .

\begin{tabular}{|c|c|c|c|c|}
\hline No & Focation & tatitude & Longitude & $\begin{array}{l}\text { Area } \\
\left(\mathbf{K m}^{2}\right)\end{array}$ \\
\hline 7 & JBG-07 & 112,282234 & $-7,520841$ & 0,785 \\
\hline 8 & JBG-08 & 112,367770 & $-7,508661$ & 0,785 \\
\hline 9 & JBG-09 & 112,370295 & $-7,478415$ & 0,785 \\
\hline 10 & JBG-10 & 112,365994 & $-7,589235$ & 0,785 \\
\hline 11 & JBG-11 & 112,282250 & $-7,579282$ & 0,785 \\
\hline 12 & JBG-12 & 112,258737 & $-7,603661$ & 0,785 \\
\hline 13 & JBG-13 & 112,267559 & $-7,637875$ & 0,785 \\
\hline 14 & JBG-14 & 112,344787 & $-7,672336$ & 0,785 \\
\hline 15 & JBG-15 & 112,361161 & $-7,665761$ & 0,785 \\
\hline 16 & JBG-16 & 112,250527 & $-7,719153$ & 0,785 \\
\hline 17 & JBG-17 & 112,197652 & $-7,598849$ & 0,785 \\
\hline 18 & JBG-18 & 112,194327 & $-7,542663$ & 0,785 \\
\hline 19 & JBG-19 & 112,210422 & $-7,505237$ & 0,785 \\
\hline 20 & JBG-20 & 112,276283 & $-7,494869$ & 0,785 \\
\hline 21 & JBG-21 & 112,119391 & $-7,458954$ & 0,785 \\
\hline 22 & JBG-22 & 112,214634 & $-7,584757$ & 0,785 \\
\hline 23 & JBG-23 & 112,313772 & $-7,699618$ & 0,785 \\
\hline & \multicolumn{3}{|c|}{ the Blue Zone } & 18,055 \\
\hline
\end{tabular}

\section{E. Placement of New Tower Zone on Map Info}

The placement of new zones should be according to 3 existing criteria: population density, Spatial Plans, and distance. Before determining the new tower zone, it must be known in advance about the location of the existing tower zone. In this final project the existing tower zones $2 \mathrm{G}$ and $3 \mathrm{G}$ are depicted in the red zone and will be illustrated in Figures 3 and 4. The existing tower zone consists of 1 telecommunication tower in each tower zone.

While the new tower zone serves to overcome the area that has not covered by the existing tower zone. The location of the new tower zone must also be according to the 3 criteria specified ie population density, Spatial Plans, and Distance. The new tower zone in MapInfo is depicted with blue zones. The result of the new tower zone can be seen in figure 5 and the result of combination in figure 6 .

\section{F. Decision Support System BTS Location with Analytical Hierarchy Process Method}

Assessment of BTS locations that have been determined previously with 3 existing criteria of population density, Spatial Plans, and Distance. Assessment results can be seen in table 13 and the results of calculations in table 14 .

TABLE 12 NEW TOWER DATA

\begin{tabular}{|l|l|l|l|l|}
\hline No & \multirow{2}{*}{ ocation } & atitude & Longitude & $\begin{array}{l}\text { Area } \\
\left(\mathbf{K m}^{2}\right)\end{array}$ \\
\hline 1 & JBG-01 & 112,132556 & $-7,553593$ & 0,785 \\
\hline 2 & JBG-02 & 112,163266 & $-7,473093$ & 0,785 \\
\hline 3 & JBG-03 & 112,219293 & $-7,417982$ & 0,785 \\
\hline 4 & JBG-04 & 112,247688 & $-7,426572$ & 0,785 \\
\hline 5 & JBG-05 & 112,310092 & $-7,383929$ & 0,785 \\
\hline 6 & JBG-06 & 112,267391 & $-7,450437$ & 0,785 \\
\hline
\end{tabular}




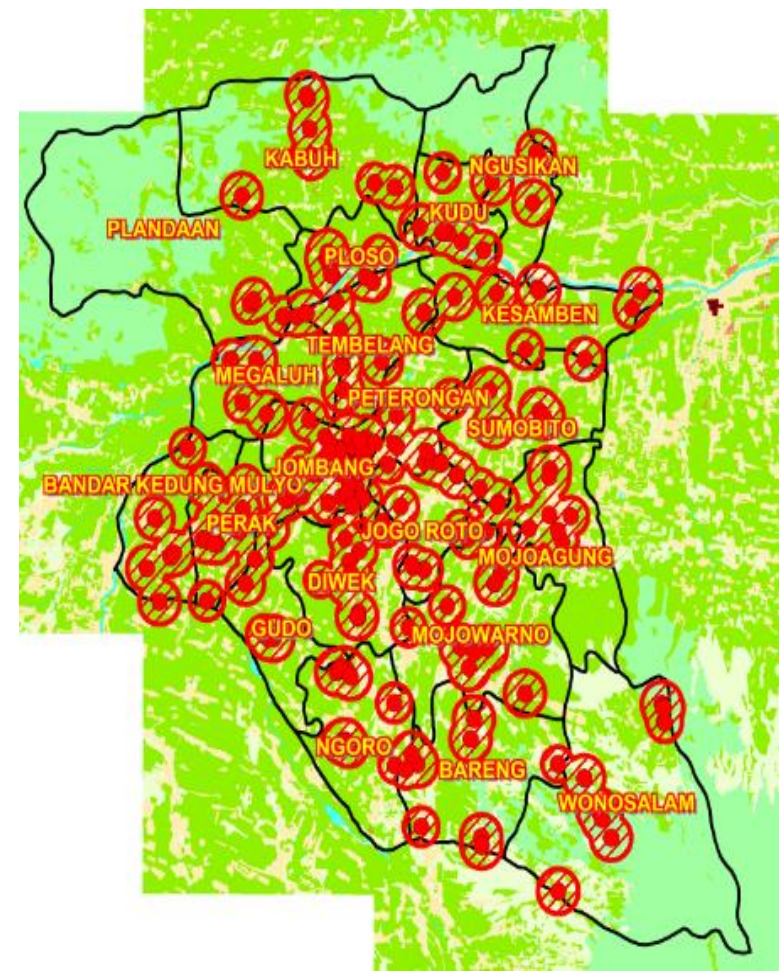

FIGURE 3 EXISTING TOWER ZONE 2G

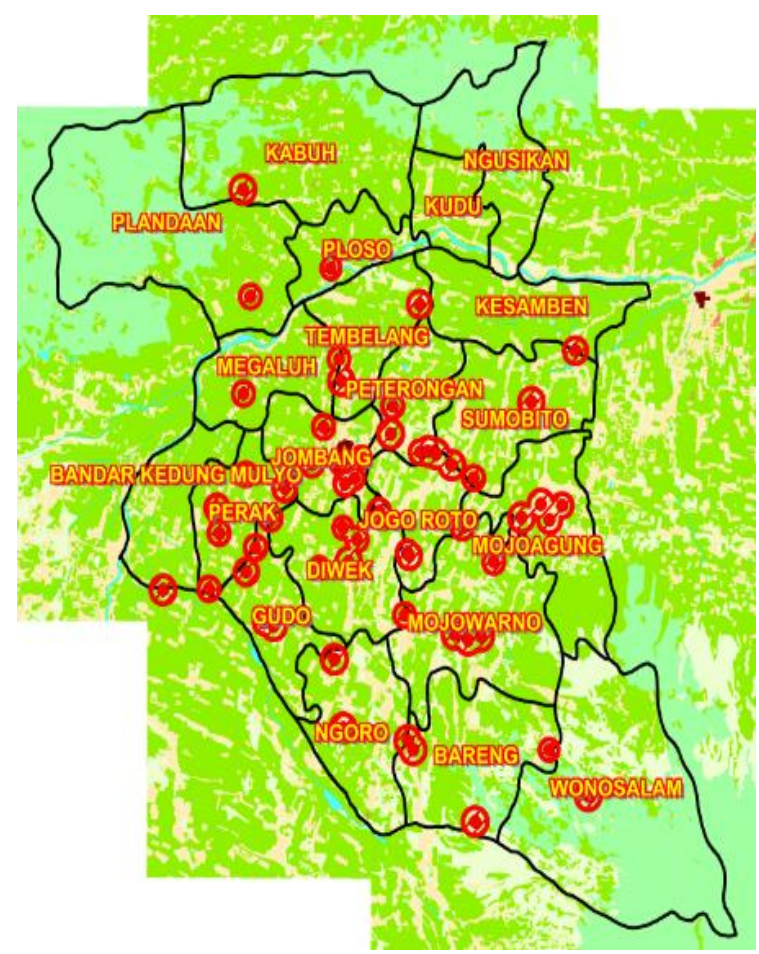

FIGURE 4 EXISTING 3G TOWER ZONE

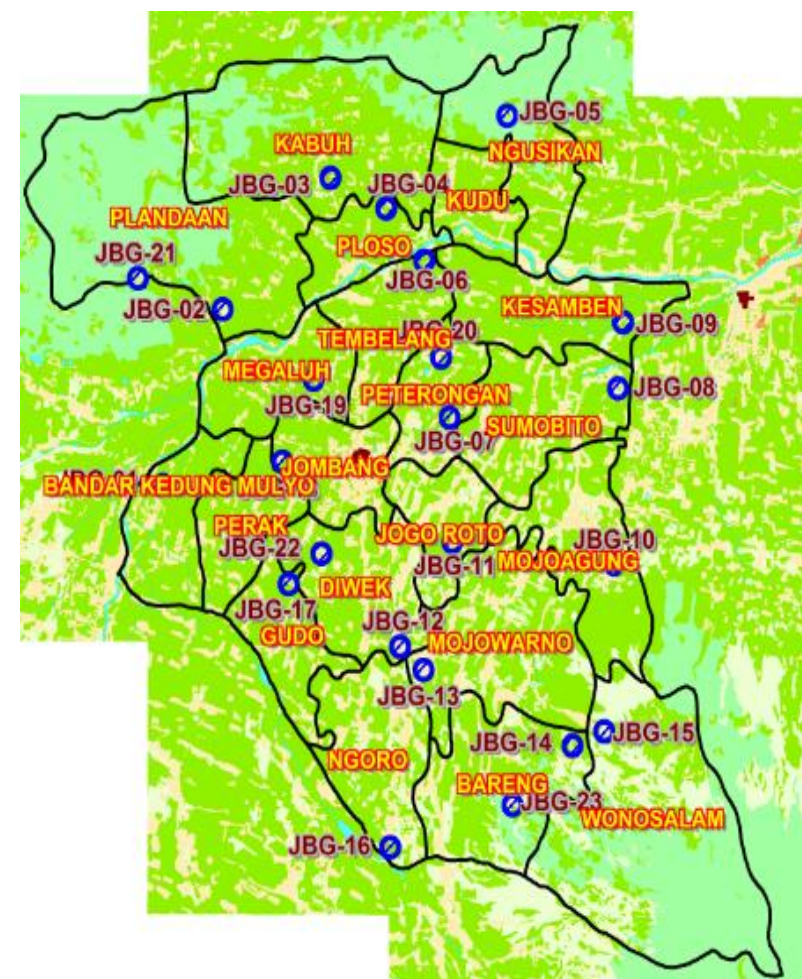

FIGURE 5 NEW TOWER ZONE

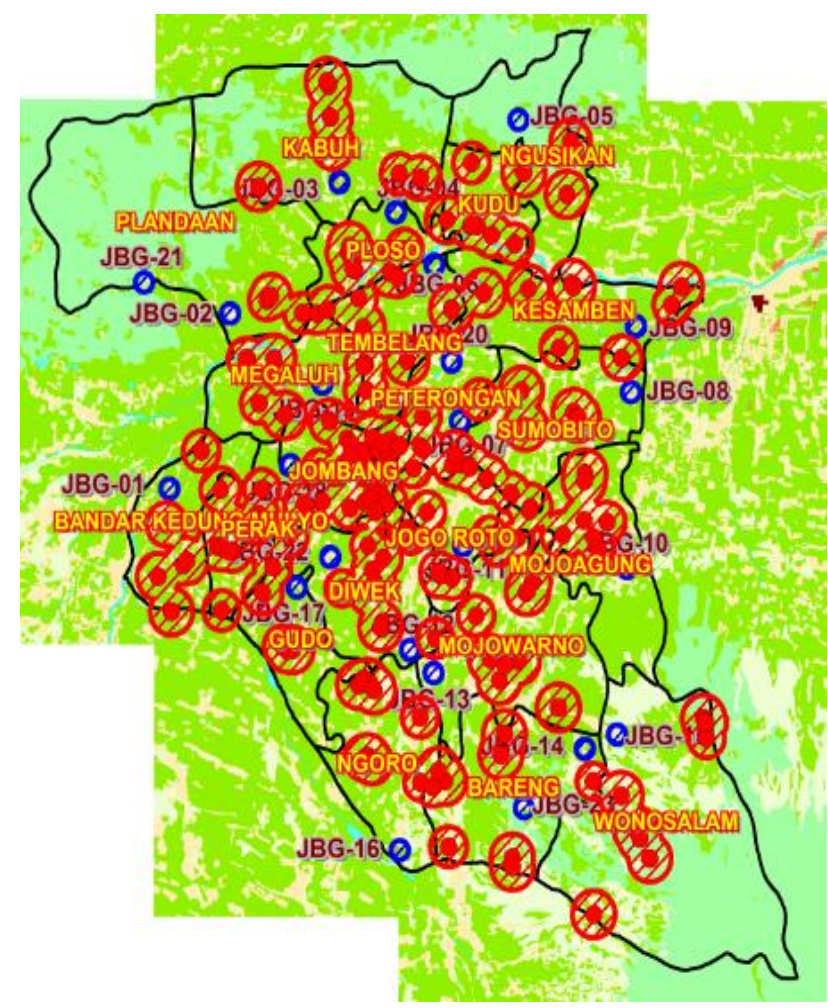

FIGURE 6 COMBINATION RESULT 
JAREE-Journal on Advance Research in Electrical Engineering Volume3, Number 2, October 2019

TABLE 13 DETERMINATION OF SUB-CRITERIA FOR BTS LOCATION IN JOMBANG REGENCY ACCORDING TO AHP METHOD

\begin{tabular}{|l|l|l|l|l|}
\hline No & location & Pensity & $\mathbf{P}$ & Pistance \\
\hline 1 & JBG-01 & Enough & Good & Good \\
\hline 2 & JBG-02 & Less & Less & Less \\
\hline 3 & JBG-03 & Less & Enough & Good \\
\hline 5 & JBG-04 & Less & Good & Good \\
\hline 6 & JBG-05 & Less & Less & Less \\
\hline 7 & JBG-06 & Enough & Good & Less \\
\hline 8 & JBG-08 & Good & Enough & Enough \\
\hline 9 & JBG-09 & Enough & Enough & Enough \\
\hline 10 & JBG-10 & Good & Good & Less \\
\hline 11 & JBG-11 & Enough & Enough & Enough \\
\hline 12 & JBG-12 & Good & Less & Good \\
\hline 13 & JBG-13 & Good & Good & Enough \\
\hline 14 & JBG-14 & Enough & Less & Enough \\
\hline 15 & JBG-15 & Less & Less & Less \\
\hline 16 & JBG-16 & Good & Less & Good \\
\hline 17 & JBG-17 & Enough & Less & Enough \\
\hline 18 & JBG-18 & Good & Good & Good \\
\hline 19 & JBG-19 & Less & Enough & Good \\
\hline 20 & JBG-20 & Good & Enough & Enough \\
\hline 21 & JBG-21 & Less & Less & Less \\
\hline 22 & JBG-22 & Good & Less & Good \\
\hline 23 & JBG-23 & Enough & Less & Enough \\
\hline
\end{tabular}

TABLE 14 ASSESSMENT OF SUB-CRITERIA BTS LOCATION DETERMINATION IN JOMBANG REGENCY WITH AHP METHOD

\begin{tabular}{|c|c|c|c|c|c|}
\hline No & Cocation & Pensity & PP & Distance & $\begin{array}{l}\text { AHP Method } \\
\text { Result }\end{array}$ \\
\hline 1 & JBG-01 & 0,23 & 0,27 & 0,18 & 0,68 \\
\hline 2 & JBG-02 & 0,09 & 0,05 & 0,04 & 0,18 \\
\hline 3 & JBG-03 & 0,09 & 0,11 & 0,18 & 0,38 \\
\hline 4 & JBG-04 & 0,09 & 0,27 & 0,18 & 0,54 \\
\hline 5 & JBG-05 & 0,09 & 0,05 & 0,04 & 0,18 \\
\hline 6 & JBG-06 & 0,23 & 0,27 & 0,04 & 0,54 \\
\hline 7 & JBG-07 & 0,55 & 0,11 & 0,08 & 0,74 \\
\hline 8 & JBG-08 & 0,55 & 0,11 & 0,08 & 0,74 \\
\hline 9 & JBG-09 & 0,23 & 0,11 & 0,04 & 0,38 \\
\hline 10 & JBG-10 & 0,55 & 0,27 & 0,08 & 0,9 \\
\hline 11 & JBG-11 & 0,23 & 0,11 & 0,08 & 0,42 \\
\hline 12 & JBG-12 & 0,55 & 0,05 & 0,18 & 0,78 \\
\hline 13 & JBG-13 & 0,55 & 0,27 & 0,08 & 0,9 \\
\hline 14 & JBG-14 & 0,23 & 0,05 & 0,08 & 0,36 \\
\hline 15 & JBG-15 & 0,09 & 0,05 & 0,04 & 0,18 \\
\hline 16 & JBG-16 & 0,55 & 0,05 & 0,18 & 0,78 \\
\hline 17 & JBG-17 & 0,23 & 0,05 & 0,08 & 0,36 \\
\hline
\end{tabular}

\begin{tabular}{|l|c|c|l|l|l|}
\hline No & Location & Pensity & \$P & Distance & $\begin{array}{l}\text { lHP Method } \\
\text { Result }\end{array}$ \\
\hline 18 & JBG-18 & 0,55 & 0,27 & 0,18 & 1 \\
\hline 19 & JBG-19 & 0,09 & 0,11 & 0,18 & 0,38 \\
\hline 20 & JBG-20 & 0,55 & 0,11 & 0,08 & 0,74 \\
\hline 21 & JBG-21 & 0,09 & 0,05 & 0,04 & 0,18 \\
\hline 22 & JBG-22 & 0,55 & 0,05 & 0,18 & 0,78 \\
\hline 23 & JBG-23 & 0,23 & 0,05 & 0,08 & 0,36 \\
\hline
\end{tabular}

\section{CONCLUSION}

In the year 2019 in Jombang regency is predicted to have traffic of 22,459 Erlang and there are 418 BTS contained in 231 telecommunication towers. In 2019 also predicted the addition of 23 new tower zones with $0.5 \mathrm{~km}$ radius with total area of the zone is $18.055 \mathrm{Km} 2$. According to Analytical Hierarchy Process method with population density criterion, Spatial Plans, and distance, new tower zone that has the highest priority to be built is JBG-18 located in Jombang subdistrict and has priority value 1 . Then followed up to the fifth priority in a row as follows: JBG-10 in Mojoagung sub-district, JBG-13 in Mojowarno sub-district, JBG-12 in Diwek sub-district, and JBG-16 in Ngoro sub-district.

\section{REFERENCES}

[1] Hakim, M.Fajrul, "Optimasi Perencanaan Jumlah Base Transceiver Station (BTS) dan Kapasitas Trafik BTS Menggunakan Pendekatan Goal Programming pada Sistem Telekomunikasi Seluler Berbasis GSM”, 2012.

[2] Hamad-Ameen, Jalal Jamal, "Cell Planning in GSM Mobile", 2008.

[3] Labadja, Teguh Anhali, "Rancang Bangun Sistem Informasi Geografis (SIG) untuk pemancar GSM di kota Makassar", 2012.

[4] Turban, E, Jay, E.A., "Decision Support System and Intelligent System",fifth edition, Prentice Hall International, Inev, 1998.

[5] Kementrian Komunikasi dan Informatika,'Indikator TIK Indonesia”, 2011.

[6] Jombang Dalam Angka Tahun 2013.

[7] Suwadi, "Diktat Trafik", Institut Teknologi Sepuluh Nopember, Surabaya, Februari , 2012 